\title{
Mustard and Other Cover Crop Effects Vary on Lettuce Drop Caused by Sclerotinia minor and on Weeds
}

Tiffany A. Bensen and Richard F. Smith, University of California Cooperative Extension, Monterey County, Salinas 93901; Krishna V. Subbarao, University of California, Department of Plant Pathology, Davis 95616; Steven T. Koike, University of California Cooperative Extension; and Steven A. Fennimore and Shachar Shem-Tov, University of California, Department of Plant Sciences, Davis 95616

\begin{abstract}
Bensen, T. A., Smith, R. F., Subbarao, K. V., Koike, S. T., Fennimore, S. A., and Shem-Tov, S. 2009. Mustard and other cover crop effects vary on lettuce drop caused by Sclerotinia minor and on weeds. Plant Dis. 93:1019-1027.

Mustard cover crops have been suggested as a potential biofumigant for managing soilborne agricultural pests and weeds. We conducted several experiments in commercial lettuce fields in the Salinas Valley, CA, to evaluate the effects of mustard cover crops on lettuce drop caused by Sclerotinia minor and on weed density and seed viability. In a long-term study, we measured the effects of white and Indian mustard cover crops on the density of $S$. minor sclerotia in soil, lettuce drop incidence, weed densities, weed seed viability, and crop yield in head lettuce. We also tested broccoli and rye cover crop treatments and a fallow control. Across several short-term studies, we evaluated the density of $S$. minor sclerotia in soil, lettuce drop incidence, weed densities, and weed seed viability following cover cropping with a mustard species blend. Numbers of sclerotia in soil were low in most experimental locations and were not affected by cover cropping. Mustard cover crops did not reduce disease incidence in the long-term experiment but the incidence of lettuce drop was lower in mustard-cover-cropped plots across the short-term experiments. With the exception of common purslane and hairy nightshade, weed densities and weed seed viability were not significantly reduced by cover cropping with mustard. Head lettuce yield was significantly higher in mustard-cover-cropped plots compared with a fallow control. Glucosinolate content in the two mustard species was similar to those measured in other studies but, when converted to an equivalent of a commercial fumigant, the concentrations were much lower than the labeled rate for lettuce production. Although mustard cover cropping resulted in yield benefits in this study, there was little to no disease or weed suppression.
\end{abstract}

Lettuce drop and weeds are perennial concerns for lettuce (Lactuca sativa L.) growers in the Salinas Valley of California. Sclerotinia minor Jagger is a soilborne fungal pathogen with a wide host range that causes lettuce drop on all types of lettuce. Infection in lettuce by $S$. minor results in rapid and complete collapse of mature plants prior to harvest and can cause seasonal yield losses as high as $60 \%$ (31). The pathogen can persist in the soil in a dormant but viable sclerotial stage for many years, depending on soil conditions (31), which complicates disease management. In the Salinas Valley, growers attempt to manage lettuce drop caused by $S$. minor with post-thinning fungicide application coupled with crop rotation. Another challenge in Salinas Valley lettuce production is control of annual broadleaf weeds, which compete with lettuce plants for resources, especially during early stages of

Corresponding author: Richard F. Smith

E-mail: rifsmith@ucdavis.edu

Accepted for publication 9 June 2009.

doi:10.1094/PDIS-93-10-1019

(C) 2009 The American Phytopathological Society crop development. Weed cover greater than $25 \%$ can result in complete lettuce yield loss (17), and production costs can escalate quickly if extensive hand weeding is needed (L. Tourte and R. Smith, unpublished). Furthermore, weeds may also function as reservoirs of Lettuce mosaic virus (39) and Verticillium dahliae (35). Current weed control practice in the Salinas Valley is to apply either preemergence or post-emergence herbicides and to either leave fields as fallow beds in winter or plant a rye (Secale cereale L.) cover crop to suppress weed germination and reproduction during winter.

Cover cropping with some species of Brassicaceae has received attention in recent years as a cultural practice that may suppress soilborne pathogens and reduce the use of fungicides or fumigants. Brassicaceae cover crops also may suppress weeds more effectively than rye or other cover crops (3). The mechanism of this suppression is the release of glucosinolates from tissue when plants are tilled into soil. When plant tissue breaks down, glucosinolates are converted through enzymatic action into isothiocyanates, thiocyanates, and other compounds that are toxic to fungi, nematodes, and weeds (9). Laboratory studies show that glucosinolate prod- ucts are active against a number of soilborne pathogens, such as Sclerotinia sclerotiorum $(18,20)$, V. dahliae (26), Gaeumannomyces graminis var. tritici (1), Aphanomyces euteiches (23), and Helminthosporium solani (26), but the effects of plant-derived glucosinolates on pathogens vary widely when studied in the field. In a series of experiments with processing tomato (Lycopersicon esculentum), Hartz et al. (14) found no differences in the incidence of disease caused by $V$. dahliae, Fusarium solani, or F. oxysporum f. sp. lycopersici among plots fumigated with metam sodium, cover cropped with mustard (Brassica napus L., B. juncea (L.) Czern., and Sinapis alba L.) or a legume mix, or left fallow. In contrast, studies by Xiao et al. (38) and Subbarao et al. (33) found that the incorporation of fresh residue from a commercial broccoli (B. oleracea L. var. botrytis L.) crop after harvest significantly reduced the numbers of $V$. dahliae microsclerotia in the soil as well as the incidence of Verticillium wilt in the following cauliflower crop. Pung et al. (28) found that the incidence of lettuce drop caused by Sclerotinia minor was lower in plots cover cropped with a mixture of $B$. rapa L. and $B$. napus than in fallow plots, although disease incidence between Brassica spp. cover-cropped plots and cereal or legume cover-cropped plots did not differ significantly. In California field studies, Hao et al. (12) found that rotations with broccoli in head lettuce reduced $S$. minor sclerotia densities and lettuce drop incidence; however, these effects were significant only at high inoculum levels.

As with disease suppression, weed inhibition by glucosinolates and isothiocyanates has also been shown in laboratory studies $(4,27,36)$, but such effects have been inconsistent or weak in the field. For instance, weeds such as common lambsquarters (Chenopodium album L.) and redroot pigweed (Amaranthus retroflexus L.) were reduced to levels nearly equal to that of a standard herbicide after B. napus cover crop incorporation (2), although Norsworthy et al. (24) found that a cover crop blend of B. juncea and Sinapis alba reduced weed biomass in just one of three field sites. Haramoto and Gallandt (13) showed that weed emergence and establishment were reduced in plots with cover 
crops of B. napus and $S$. alba compared with plots left fallow but were not different between mustard- and cereal-covercropped plots.

Of the Brassicaceae, mustard cover crops (species such as B. juncea and $S$. alba) have been shown to contain potentially high concentrations of isothiocyanate-liberating glucosinolates (16) and, thus, hold potential for disease and weed control in lettuce production. To evaluate this potential, we conducted a long-term study and a series of short-term field studies to compare the effects of two mustard cover crops with broccoli and rye cover crops and a fallow control on (i) lettuce drop incidence and lettuce yield, (ii) field weed densities and the weed seed bank, and (iii) Sclerotinia minor sclerotia.

\section{MATERIALS AND METHODS}

Long-term study. A long-term experiment with one fallow and four cover crop treatments was conducted in a commercial field in the Salinas Valley, CA, over two seasons, from 2003 to 2005 . The cooperating grower managed this field using standard commercial practices for both cover crop and lettuce production. The cover crop treatments were 'Ida Gold' white mustard (Sinapis alba), 'ISCI 61' Indian mustard (B. juncea), 'Merced' rye (Secale cereale), and 'DiCicco' broccoli. Merced rye was included as a treatment because it is a commonly used cover crop in the Salinas Valley, and broccoli was tested based on results from previous work by Hao et al. (12). The experimental design was a randomized complete block with three replications of each cover crop and fallow. Plots were 12 beds wide (each bed measured $1 \mathrm{~m}$ between bed centers) and $152 \mathrm{~m}$ long.

Marking the beginning of the crop season, cover crops were sown in late summer of each year (14 August 2003 and $30 \mathrm{Au}$ gust 2004) at the rates of $115 \mathrm{~kg}$ seed/ha for Merced rye, $24 \mathrm{~kg}$ seed/ha for DiCicco broccoli and 'Ida Gold' white mustard, and $10 \mathrm{~kg} \mathrm{seed} / \mathrm{ha}$ for ISCI 61 Indian mustard using a Case International 5100 grain drill (Case International, Racine, WI). The plots were sprinkler irrigated to promote uniform cover crop emergence and grown for approximately 8 weeks before they were incorporated at early flowering by flail mowing and disking into moist soil (17 October 2003 and 25 October 2004). After cover crop incorporation, the plots were left undisturbed for approximately 1 month and then prepared for lettuce planting by further disking, ripping, chiseling, listing, and bed shaping according to local standard commercial practice. In the first season, the head lettuce crops were planted on 17 January 2004 (cv. Cannery Row) and 22 June 2004 (cv. Sniper). In the second season, lettuce was planted on 9 April and 17 August 2005 (Sniper). Lettuce was seeded at $5-\mathrm{cm}$ spacing in two rows per bed, fertilized with a preplant fertilizer, and further supplemented according to prescribed management practices, which included banded split applications of ammonium nitrate at the rate $160 \mathrm{~kg}$ of $\mathrm{N}$ per hectare (15). The lettuce plantings were sprinkler irrigated for the first month to establish the stand and switched to drip irrigation after thinning for the remainder of the season. Three weeks after seedling emergence, the lettuce was thinned to a standard spacing of $30 \mathrm{~cm}$. In the first season, the first crop was harvested on 27 April and the second crop on 20 August 2004. In the second season, the first and second crops were harvested on 20 June and 18 October 2005, respectively.

Sclerotia density and lettuce drop incidence. To determine the effect of covercrop treatments on soil sclerotia density and over time, soil samples were collected on six occasions over the two consecutive lettuce seasons. On each sampling date, a composite soil sample was collected from each third of each treatment plot to measure sclerotia density. Twelve subsamples were collected with a trowel from the upper $15 \mathrm{~cm}$ of soil from the center of each bed in a given third of each plot, then placed together in a container and mixed thoroughly, and a final sample of $100 \mathrm{~cm}^{3}$ was removed from the composite sample for testing. In the first season, samples were first collected on 28 August 2003, 14 days after the cover crops were sown; again on 6 November, 20 days after cover crop incorporation; and then on 9 July 2004, when the second lettuce crop was thinned. In the second season, samples were collected on 31 August 2004 at planting of the cover crops; again on 10 February 2005, 4 months after cover crop incorporation; and then at lettuce harvest, on 18 October 2005. Soil samples were assayed for sclerotia of Sclerotinia minor using the wet sieving method described by Subbarao et al. (32).

Lettuce drop incidence was evaluated at harvest by counting total and infected plants in a 60-m strip of the four center beds of each plot. Lettuce infected with $S$. minor was identified by collapsed and wilted wrapper leaves, soft and poorquality lettuce head, and white mycelium and black sclerotia found at the base of infected plants. Yield was measured for three of the four lettuce crops (27 April 2004, 20 June 2005, and 18 October 2005) by cutting and weighing either 32 or 40 healthy heads arbitrarily selected from the four center beds of each plot. Heads were stripped of outer wrapper leaves, as is done in commercial harvests, prior to being weighed.

Cover crop biomass and glucosinolate content. In both seasons of the long-term experiment, immediately preceding incorporation, cover crops were sampled to estimate total biomass production. Samples were collected from three $1-\mathrm{m}^{2}$ areas in each plot by clipping all plants at the soil level, placing all foliage in a container, and weighing the material. Random subsamples of fresh biomass from each plot were weighed in the laboratory, oven dried at $65^{\circ} \mathrm{C}$ for $72 \mathrm{~h}$, and reweighed to calculate moisture content.

Mustard cover crops were sampled at early flowering in 2004 to determine glucosinolate content. From each mustard cover crop plot within each block, a sample of five plants was collected by clipping plants at the soil line, taking care to not damage any leaves or stems, and kept cold during prompt transit to the freezer for storage until freeze drying. Plants were freeze dried and ground using a Thomas Wiley Mini Mill (Thomas Scientific, Swedesboro, NJ) with a 40-mesh screen, and the samples were sent to a University of Idaho laboratory for glucosinolate analysis, where glucosinolate content was determined using a modified procedure described by Daun et al. (6) and Daun and McGregor (7).

Fumigation potential of Brassica cover crops from the long-term experiment was calculated by converting glucosinolate content to an equivalent of metam sodium, the active ingredient in the commercial soil fumigant Vapam (3.18 lbs a.i./gal, watersoluble liquid; Amvac Chemical Corporation, Los Angeles). This conversion generously assumes that $1 \mathrm{~mol}$ of glucosinolate is equal to $1 \mathrm{~mol}$ of methyl isothiocyanate (MITC), the biocidal component of metam sodium. We first calculated the MITC content in Vapam as MITC at 0.0018 $\mathrm{g} /$ liter $\times 129 \mathrm{~g} / \mathrm{mol}=\mathrm{MITC}$ at $1.40 \times 10^{-5}$ $\mathrm{mol} /$ liter, which was then converted to total glucosinolate concentration in dry cover crop tissue (mole per hectare) by multiplying mean total glucosinolate and mean dry biomass yield. Finally, the moles of glucosinolates per hectare in the cover crops was divided by moles of MITC per liter in Vapam to estimate the equivalent of MITC in the cover crops. For comparison with other published data, we converted glucosinolate concentration to an area basis using mean dry weight biomass measurements for broccoli and the two mustard cover crops.

Weed densities and weed seed bank. Weed populations in the long-term study were characterized from counts made in the middle of the bed, which was not treated with herbicide. Evaluations were conducted for three of the four lettuce crops (spring 2004, summer 2004, and spring 2005). Species and numbers of each were counted at thinning (4 to 5 weeks following seeding). Counts were made from six subsamples per plot for a total sample area per plot of $5.4 \mathrm{~m}^{2}$ in 2004 and $1.8 \mathrm{~m}^{2}$ in 2005 and converted to numbers of weeds per square meter for statistical analysis.

Changes in the weed seed bank resulting from cover cropping were evaluated in the long-term experiment from three soil- 
sampling events over the two seasons. To first establish viable weed seed densities in the soil, a baseline sample was collected shortly after cover crop planting in the first season (10 September 2003). Soil samples were collected from each plot by sampling along a 97.6-m diagonal transect across each plot; 16 subsamples were collected with a soil probe $(5 \mathrm{~cm}$ in diameter by 7 $\mathrm{cm}$ deep) from each unprepared plot and mixed into a single composite sample. To determine treatment effects after one season, soil was sampled again following cover crop incorporation in the second season (13 October 2004). Baseline weed seed densities were found to be low; therefore, for this sampling, we increased the volume and reduced the number of subsamples to five for each plot. The third, final sampling was conducted midway through the second season (7 March 2005), following the protocol of the second sampling. For each sampling, the composite samples were air dried in trays $\left(676 \mathrm{~cm}^{2}\right.$ by $5 \mathrm{~cm}$ deep) and incubated for 42 days in an unheated greenhouse. Every 2 weeks, the emerged weed seedlings were identified, counted, and removed. After each weed count, the soil was stirred, returned to the trays, and watered for an additional germination period. After 6 weeks of incubation, soil samples were air dried for 2 to 3 days, and weed seeds were extracted by elutriation with a $250-\mu \mathrm{m}$ (60-mesh) screen. Elutriated samples were air dried and sieved through a 1.7-mm (12-mesh) screen to remove gravel, which was discarded, and the weed seed was separated from the remaining soil following a salt floatation procedure similar to the method described by Malone (19). Floating organic matter was collected on a $600-\mu \mathrm{m}$ (30-mesh) screen, and seed were separated from the floating organic matter, identified to species, and tested for viability by applying pressure to check if the seed were firm or hollow. The total number of germinated and nongerminated seed was determined and converted to the number of viable seed per square meter.

Short-term studies. The effect of a mustard cover crop blend, 'Caliente 119' (a proprietary mixture of Sinapis alba and $B$. juncea), on soilborne Sclerotinia minor and weeds was evaluated in six experiments in four commercial fields in the Salinas Valley (hereafter referred to as Gonzales-A, -B, -C, -D, Somavia, and
Spreckels; Table 1). Cover crop and fallow treatments were arranged in randomized complete block designs with plots measuring from 7 to 12 beds wide $(1 \mathrm{~m}$ between bed centers) and 12 to $18 \mathrm{~m}$ long (Table 1). Gonzales-A and Somavia were replicated two times and Gonzales-B, -C, -D, and Spreckels were replicated three times. In each experiment, cover crops were sown with seed at 11 to $17 \mathrm{~kg} / \mathrm{ha}$ using the grower's equipment. Fallow plots were either left unplanted or sprayed with glyphosate after cover crop seedlings reached the one- to two-true-leaf stage. Cover crops were incorporated at flowering, approximately 8 to 10 weeks after emergence, and the plots were left undisturbed for 3 to 4 weeks until field preparation for planting lettuce in the spring (Table 1).

Sclerotia density, lettuce drop incidence, and cover crop biomass. In four of the short-term experiments (Gonzales-B, -C, -D, and Spreckels), soil samples were collected from plots at the time of covercrop planting and again after cover-crop incorporation, at an early stage of the lettuce crop, to assay for sclerotia of $S$. $m i$ nor. As in the long-term experiment, composite soil samples were collected from each third of a plot by sampling soil from the top $15 \mathrm{~cm}$ of each bed with a trowel. These subsamples were mixed thoroughly and a final soil sample of $100 \mathrm{~cm}^{3}$ was removed for testing. In the Gonzales-B and Gonzales- $\mathrm{C}$ experiments, samples were collected approximately 40 days after cover crop incorporation. At the Gonzales$\mathrm{D}$ and Spreckels experiments, samples were collected approximately 75 and 135 days, respectively, after cover crop incorporation. We calculated the ratio of sclerotia recovered before and after cover crop incorporation to test for an effect of the mustard cover crop on soil sclerotial densities. At harvest in all six experiments, we evaluated disease incidence per treatment from multiple samples in each replicate treatment plot. Percent incidence of lettuce drop was determined by counting the total number of plants and the number of plants infected with $S$. minor for several beds per plot and standardized to a measure of infection per $30.5 \mathrm{~m}$ of each plot. Cover-crop biomass was measured at Gonzales- $\mathrm{C}$ and Spreckels following the methods of the long-term experiment.

Weed densities and weed seed viability. Weed populations were characterized in four of the six short-term experiments (Gonzales-A, -D, Somavia, and Spreckels) at the thinning stage (4 to 5 weeks following seeding) of the lettuce crop. Weed densities were determined by identifying and counting the number of weed seedlings within a given area in square meters of several beds (subsamples) within treatment plots. As in the long-term experiment, the area evaluated for weeds varied and depended on weed abundance at the time of counting. At the Gonzales-A site, we counted all weeds within $3.72 \mathrm{~m}^{2}$ on eight separate beds in each treatment plot within each of the two blocks. At the Somavia site, in two blocks with each treatment plot, weeds were counted over $9.29 \mathrm{~m}^{2}$ on nine beds. At the Spreckels and Gonzales-D sites, weeds were counted within $2.32 \mathrm{~m}^{2}$ on six separate beds in each treatment plot within each of the three blocks. All counts were converted to numbers of weeds per square meter for statistical analysis.

In the Gonzales-B experiment, the effect of cover cropping on weed seed viability was tested by burying nylon-mesh bags, each with 25 seeds of four common agricultural weeds (common chickweed, Stellaria media (L.) Vill; common purslane, Portulaca oleracea L.; common knotweed, Polygonum arenastrum Boreau; and burning nettle, Urtica urens L.), into mustardcover-crop and fallow plots immediately following cover-crop incorporation. A single bag was buried in each treatment plot of the three replicate blocks to a depth of $15 \mathrm{~cm}$ and left in the field for 1 week. After retrieval, seed viability was determined in the laboratory by the tetrazolium chloride (TTC) test described by Grabe (11) and Flemion and Poole (10). Seed were cut and incubated on a filter with 1 $\mathrm{ml}$ of $1 \%$ TTC for $24 \mathrm{~h}$ at $21^{\circ} \mathrm{C}$. After incubation, seed viability was verified under the microscope.

Statistical analysis. In the long-term study, differences in soil sclerotia density, lettuce drop incidence, and lettuce head weight and yield among cover crop treatments and sampling periods, and resulting from the interaction between treatment and sampling period, were each tested with a repeated-measures analysis of variance (ANOVA) model. This analysis and all other analyses were performed using restricted maximum likelihood estimation of parameters with the MIXED procedure in

Table 1. Experimental details and timeline for short-term studies evaluating lettuce drop incidence, weed abundance, and yield in head lettuce plots planted to different cover crops

\begin{tabular}{|c|c|c|c|c|c|c|c|}
\hline Experiment ID & Soil type & $\begin{array}{c}\text { Irrigation } \\
\text { method }\end{array}$ & $\begin{array}{l}\text { Plot size } \\
\text { (m) }\end{array}$ & $\begin{array}{c}\text { Cover crop } \\
\text { planting date }\end{array}$ & $\begin{array}{c}\text { Cover crop } \\
\text { incorporation date }\end{array}$ & Lettuce type & $\begin{array}{c}\text { Lettuce planting } \\
\text { date }\end{array}$ \\
\hline Gonzales-A & Metz fine sandy loam & Sprinkler & 15.2 by 15.2 & 7 May 2003 & 28 June 2003 & Crisphead & 14 July 2003 \\
\hline Somavia & Cropley silty clay & Sprinkler & 6. & 5 Jun & 2003 & head & gust 2003 \\
\hline Gonzales-B & Chualar loam & Sprinkler & 12.2 by 12.2 & 10 November 2003 & 12 March 2004 & Crisphead & 7 April 2004 \\
\hline Gonzales-C & Mocho silty clay loam & Drip & 12.2 by 12.2 & 10 November 2003 & 11 March 2004 & Romaine & 29 March 2004 \\
\hline Spreckels & Mocho silty loam & Furrow & 8.0 by 15.2 & 26 August 2004 & 22 October 2004 & Crisphead & 13 January 2005 \\
\hline Gonzales-D & Mocho silty clay loam & Drip & 12.2 by 12.2 & 12 October 2004 & 16 December 2004 & Crisphead & 2 February 2005 \\
\hline
\end{tabular}


SAS (version 9.1; SAS Institute, Inc., Cary, NC). Significant differences among least-squares means for sclerotia density, lettuce drop incidence, and lettuce yield were separated using pairwise $t$ tests. Differences in biomass among the cover crops for the 2 years were tested with a repeatedmeasures ANOVA and, when effects were significant, least-squares means were separated by $t$ tests of pairwise differences. Soil sclerotia density and lettuce drop incidence data failed to meet the assumption of normality according to a significant ShapiroWilk test statistic; therefore, these response variables were $\log$ and arcsine transformed, respectively. Degrees of freedom for repeated-measures models were approximated using the Kenward-Rogers method.

For the short-term experiments, because the experimental design and treatments were the same in each experiment, we combined data from all experiments for analysis. Using two-way ANOVA and data from four experiments (Gonzales-B, -C, $-\mathrm{D}$, and Spreckels), we tested for an effect of the mustard cover crop on sclerotia density by analyzing the ratio of sclerotia recovered from before and after cover crop incorporation as the response variable. With data from all six experiments, we used a two-way ANOVA to test for a cover crop effect on the incidence of lettuce drop with the percentage of diseased heads at harvest as the response variable. In both tests, the ANOVA model included the main effects of experiment site, treatment (mustard cover crop and fallow), and interactive effect of site and treatment. In each test, least-squares mean separation was performed using pairwise $t$ tests. Ratio and percent disease incidence data failed to meet the assumption of normality according to a significant Shapiro-Wilk test statistic but were successfully log transformed to approximate normality.
The effects of cover crop treatment were tested for each of the most abundant weed species in the long- and short-term experiments. Density data in the long-term experiment were analyzed using a repeated-measures ANOVA model with cover-crop treatment, sampling date, and the interaction between treatment and sampling date as factors. Degrees of freedom for the repeated-measures model were approximated with the Kenward-Rogers method. For each of the short-term experiments, densities of the most abundant weed species were tested for differences between the mustard cover crop and fallow treatments with ANOVA. Data for $C$. album in the Somavia experiment and for all weed species at the Spreckels experiment failed to meet the assumption of normality according to a significant Shapiro-Wilk test statistic and were successfully log transformed to approximate normality. Data for all weed species at the GonzalesA and -D experiments could not be normalized and were analyzed using the nonparametric Friedman's test, in which data were ranked for analysis with ANOVA.

To examine changes in the viable weed seed densities, we tested for differences in the number of viable weed seed among or between cover-crop treatments and over time in the long-term experiment with a repeated-measures ANOVA model. Seed of some weed species were encountered in negligible numbers or infrequently; therefore, data from these species were not analyzed. When weed species with sufficient data for analysis could not be transformed to achieve normality, we opted to proceed with the ANOVA but to obtain $P$ values with randomization tests because the repeated measures in these experiments precluded use of a nonparametric test. Randomization tests were completed with 1,000 iterations within the SAS MIXED procedure using a macrowrapper (5). When statistically significant, least-squares means were separated for main effects using pairwise tests and $P$ values again obtained with randomization tests. Significant interactions between cover-crop treatment and time were followed with tests of simple effects of time within treatment. Data from the 2004 weed seed bag experiment were analyzed using a oneway ANOVA, with the exception of common chickweed. Viability percentage of chickweed seed could not be transformed to meet parametric assumptions of normality based on the Shapiro-Wilk test; therefore, these data were analyzed using the nonparametric Kruskal-Wallis test for a one-factor model.

\section{RESULTS}

Sclerotia density in soil. In the longterm experiment, soil sclerotia density did not differ among the treatment plots $\left(F_{4,10.5}\right.$ $=0.81, P=0.545)$. The numbers of sclerotia recovered in soil were low; over all treatments and sampling dates, sclerotia averaged (mean \pm standard error of the mean $[\mathrm{SEM}]) 3.5 \pm 0.23$ per $100 \mathrm{~cm}^{3}$ of soil. Sclerotia densities were not significantly different in the first season, among the first three sampling dates (28 August 2008, 6 November 2003, and 9 July 2004; Table 2), or in the second season, among the last three sampling dates (31 August 2004, 10 February 2005, and 18 October 2005; Table 2), although densities increased significantly in all treatment plots after the first season (sampling date effect: $\left.F_{5,200}=8.78, P<0.0001\right)$. The effect of sampling date was consistent for each treatment $\left(F_{20,200}=0.85, P=0.645\right)$.

In the short-term experiments, mean ratios of sclerotia counts before and after cover crop incorporation did not differ significantly among any of the short-term

Table 2. Back-transformed means (followed by $95 \%$ confidence limits) for soil sclerotia and lettuce drop percentage and arithmetic least squares means ( \pm standard error of the mean) for lettuce yield with statistical differences among treatment plots and sampling dates of each lettuce crop from long-term head lettuce experiment at Chualar, $\mathrm{CA}^{\mathrm{x}}$

\begin{tabular}{|c|c|c|c|}
\hline Factor & Soil sclerotia (counts/100 $\left.\mathrm{cm}^{3}\right)^{\mathrm{y}}$ & Lettuce drop $(\%)^{\mathrm{z}}$ & Yield (metric tons/ha) \\
\hline \multicolumn{4}{|l|}{ Cover crop treatment } \\
\hline Merced rye & $1.85(1.21,2.68) \mathrm{a}$ & $1.54(1.27,1.85) \mathrm{a}$ & $56.3 \pm 3.1 \mathrm{ab}$ \\
\hline Broccoli & $2.72(1.88,3.81) \mathrm{a}$ & $2.57(2.21,2.96) \mathrm{a}$ & $56.3 \pm 3.1 \mathrm{ab}$ \\
\hline White mustard & $2.14(1.43,3.05) \mathrm{a}$ & $2.44(2.09,2.82) \mathrm{a}$ & $58.3 \pm 3.1 \mathrm{~b}$ \\
\hline Indian mustard & $2.76(1.91,3.86) \mathrm{a}$ & $2.48(2.12,2.86) \mathrm{a}$ & $58.8 \pm 3.1 \mathrm{~b}$ \\
\hline Fallow control & $2.32(1.57,3.29) \mathrm{a}$ & $2.04(1.72,2.39)$ a & $53.2 \pm 3.1 \mathrm{a}$ \\
\hline \multicolumn{4}{|l|}{ Sampling dates } \\
\hline 28 August 2003 (at cover crop planting) & $1.37(0.85,2.04) \mathrm{a}$ & - & - \\
\hline 6 November 2003 (post cover crop incorporation) & $1.71(1.10,2.49) \mathrm{a}$ & - & - \\
\hline 27 April 2004 (first lettuce crop harvest) & - & $2.35(2.04,2.69) \mathrm{a}$ & $47.8 \pm 3.0 \mathrm{a}$ \\
\hline 9 July 2004 (early stage lettuce) & $1.53(1.05,2.12) \mathrm{a}$ & - & - \\
\hline 19 August 2004 (second lettuce crop harvest) & - & $1.26(1.04,1.52) \mathrm{b}$ & - \\
\hline 31 August 2004 (at cover crop planting) & $2.90(2.16,3.82) \mathrm{b}$ & - & - \\
\hline 10 February 2005 (early stage lettuce) & $3.32(2.49,4.33) b$ & - & - \\
\hline 20 June 2005 (third lettuce crop harvest) & - & $1.61(1.35,1.89) \mathrm{b}$ & $73.7 \pm 3.0 \mathrm{~b}$ \\
\hline 4 October 2005 (late stage lettuce) & $4.08(3.10,5.29) \mathrm{b}$ & - & - \\
\hline 18 October 2005 (fourth lettuce crop harvest) & - & $3.99(3.58,4.42) \mathrm{c}$ & $48.3 \pm 3.0 \mathrm{a}$ \\
\hline
\end{tabular}

${ }^{\mathrm{x}}$ Within factors for each response variable, means followed by the same letter are not significantly $(P>0.05)$ different according to pairwise $t$ tests; - indicates that data were not collected on this sampling date for this response variable.

${ }^{\mathrm{y}}$ Data were log transformed for statistical analysis; back-transformed means are presented.

${ }^{\mathrm{z}}$ Data were arcsine transformed for statistical analysis; back-transformed means are presented. 
experiments $\left(F_{3,14}=0.380, P=0.772\right)$, between cover-cropped and fallow plots $\left(F_{1,14}=0.240, P=0.629\right)$, or because of the experiment site-treatment interaction $\left(F_{3,14}=1.06, P=0.397\right)$. In all four experiments, the ratios in both the covercropped and fallow plots were $>1$ (overall mean $=3.67 \pm 0.841$ ), indicating that sclerotia densities decreased in plots over time, regardless of the experimental treatment. Mean densities of sclerotia before covercrop incorporation varied considerably and were all higher than found in the long-term experiment (Table 3). After cover-crop incorporation, mean sclerotial densities at Gonzales-B and Spreckels were similar to the highest densities measured in the longterm experiment; however, at Gonzales-C and $-\mathrm{D}$, densities were two or more times the highest densities of the long-term experiment (Table 3).

Lettuce drop incidence and lettuce yield. In the long-term experiment, mean lettuce drop incidence was generally low $(2.39 \pm 0.19 \%)$ across the four lettuce crops (Table 2) and did not vary significantly among the cover-crop and fallow treatments $\left(F_{4,8}=3.57, P=0.059\right)$. Percent disease incidence differed significantly among the four different lettuce crops $\left(F_{3,30}=43.46, P<0.0001\right)$. Differences in disease incidence among the treatments were consistent across the sampling dates (i.e., the interaction of these factors was not statistically significant; $F_{12,30}=1.24, P$ $=0.306$ ). Among the lettuce crops, disease caused by Sclerotinia minor was highest in the last lettuce crop in October 2005, lowest in the second and third (August 2004 and June 2005) crops, and intermediate in the first (April 2004) crop (Table 2). Mean head weight did not differ significantly among the cover-crop treatments $\left(F_{4,8}=\right.$ $3.12, P=0.080$; overall mean $=0.76 \pm$ $0.03 \mathrm{~kg}$ ) but differed significantly among sampling dates for the different lettuce crops $\left(F_{2,20}=306.68, P=<0.0001\right)$. Mean head weight in the June 2005 lettuce crop $(0.98 \pm 0.01 \mathrm{~kg})$ was significantly higher than head weight in the April 2004 and October 2005 crops $(0.65 \pm 0.02$ and 0.66 $\pm 0.02 \mathrm{~kg}$, respectively). This difference among lettuce crops was the same for all treatments (i.e., nonsignificant interaction of sampling date and treatment, $F_{8,20}=$ $0.830, P=0.586)$. Lettuce yields varied significantly with cover-crop treatment $\left(F_{4,8}=4.24, P=0.039\right)$ and among the lettuce crops $\left(F_{2,20}=241.06, P=<0.0001\right)$. Mean lettuce yields across the three crops were highest from the two mustard-covercropped plots; yields from these plots differed significantly from yield from the fallow plots (Table 2). Mean lettuce yields from the rye and broccoli plots were intermediate and did not differ significantly from either the mustard-cover-crop or fallow plots (Table 2). The interaction between treatment and sampling date was not significant for yield $\left(F_{8,20}=0.51, P=\right.$ 0.832; Table 2).

Lettuce drop incidence in the short-term experiments differed significantly by experiment $\left(F_{5,12.1}=113.63, P=<0.0001\right)$ and generally was low, except at the Spreckels site (Table 3). Absolute percent disease incidence was significantly reduced in plots with mustard cover crops compared with bare plots $\left(F_{1,12}=9.15, P=\right.$ 0.011; Table 3). Although this effect was not statistically different among experiments (experiment-treatment: $F_{5,7.63}=$ 2.36, $P=0.139$ ), the magnitude of this effect varied considerably among the experiments.

Cover crop biomass and glucosinolates. Dry weight biomass differed significantly $\left(F_{3,13.1}=40.96, P<0.0001\right)$ among the four cover crops in the longterm experiment, and total dry weight biomass was significantly $\left(F_{1,40.9}=92.11\right.$, $P<0.0001)$ greater in $2003(5.06 \pm 0.15$ metric tons/ha) than in 2004 (3.21 \pm 0.13 metric tons/ha). The pattern of biomass yield among the cover crops was the same in both years (nonsignificant treatmentyear interaction, $F_{3,40.9}=2.31, P=0.091$ ); rye and white mustard produced the most biomass, followed by Indian mustard, and broccoli yielded the least biomass (Table 4). The mustard cover crop blend measured in the short-term experiments yielded slightly more biomass than in the longterm experiment; in the Gonzales-D experiment, dry weight biomass averaged $5.22 \pm 0.30$ metric tons/ha and, in the Spreckels experiment, $5.47 \pm 0.25$ metric tons/ha.

Total glucosinolate content in the two mustard cover crops collected from the long-term experiment was very similar: Indian mustard (ISCI 61) $=16.2 \pm 2.1$ $\mu \mathrm{mol} / \mathrm{g}$ of dried tissue and white mustard (Idagold) $=15.8 \pm 2.3 \mu \mathrm{mol} / \mathrm{g}$ of dried tissue. However, the hydrolysis products of the glucosinolates differed between the two species. Of total glucosinolates, Indian mustard had a higher proportion of aliphatic isothiocyanates $(91.5 \%)$ compared with white mustard, which had a higher proportion of aromatic isothiocyanates $(94.7 \%)$. The predominant glucosinolate in Indian mustard was 2-propenyl, whereas two glucosinolates, benzyl and 4hydroxybenzyl, were detected at a ratio of approximately $1: 3$ in white mustard. Despite little difference in total glucosinolate tissue content of the two mustard cultivars, white mustard yielded significantly more biomass and, correspondingly, greater potential for biofumigation. Total glucosinolate content per area for white mustard was calculated as $7,589 \mu \mathrm{mol} / \mathrm{m}^{2}$ compared with $6,323 \mu \mathrm{mol} / \mathrm{m}^{2}$ for Indian mustard.

Table 4. Least-squares means and statistical differences for dry weight biomass from covercrop treatments at the long-term experiment at Chualar, CA

\begin{tabular}{lc}
\hline $\begin{array}{c}\text { Cover crop } \\
\text { treatment }\end{array}$ & $\begin{array}{c}\text { Mean biomass } \\
\text { (metric tons/ha) } \pm \text { standard } \\
\text { error of the mean }\end{array}$ \\
\hline Merced rye & $5.20 \pm 0.43 \mathrm{a}$ \\
Broccoli & $2.21 \pm 0.18 \mathrm{~b}$ \\
White mustard & $4.60 \pm 0.25 \mathrm{a}$ \\
Indian mustard & $3.77 \pm 0.31 \mathrm{c}$ \\
\hline
\end{tabular}

Table 3. Arithmetic least squares means ( \pm standard error of the mean) for soil sclerotia counts before and after cover crop incorporation and back-transformed least-squares means (followed by $95 \%$ lower and upper confidence limits), with statistical differences, for sclerotia ratio and lettuce drop incidence by site and by treatment in the short-term experiments in Salinas, $\mathrm{CA}^{\mathrm{x}}$

\begin{tabular}{|c|c|c|c|c|}
\hline \multirow[b]{2}{*}{ Factor } & \multicolumn{2}{|c|}{ Soil sclerotia (counts/100 $\mathrm{cm}^{3}$ ) } & \multirow[b]{2}{*}{ Soil sclerotia ratio pre:post ${ }^{\mathbf{y}}$} & \multirow[b]{2}{*}{ Lettuce drop $(\%)^{\mathrm{z}}$} \\
\hline & Pre & Post & & \\
\hline \multicolumn{5}{|l|}{ Short-term experiments } \\
\hline Gonzales-A & - & - & - & $1.66(1.13,2.24) \mathrm{a}$ \\
\hline Gonzales-B & $9.5 \pm 3.6$ & $4.17 \pm 3.6$ & $2.2(1.02,4.85) \mathrm{a}$ & $0.84(0.43,1.29)$ a \\
\hline Gonzales-C & $34.0 \pm 3.6$ & $10.33 \pm 3.2$ & $3.5(1.58,7.54) \mathrm{a}$ & $5.62(4.83,6.47) \mathrm{b}$ \\
\hline Gonzales-D & $31.0 \pm 3.9$ & $14.06 \pm 3.2$ & $2.2(1.00,4.78) \mathrm{a}$ & $5.55(4.61,6.56) b$ \\
\hline Somavia & - & - & - & $3.76(2.69,4.96) \mathrm{c}$ \\
\hline Spreckels & $7.8 \pm 3.2$ & $5.50 \pm 3.2$ & $2.1(0.97,4.62) \mathrm{a}$ & $16.11(14.57,17.73) \mathrm{d}$ \\
\hline \multicolumn{5}{|l|}{ Treatment } \\
\hline Mustard cover crop & $19.7 \pm 2.1$ & $8.39 \pm 1.8$ & $2.7(1.52,4.78) \mathrm{a}$ & $4.29(3.82,4.77) \mathrm{a}$ \\
\hline Fallow & $21.4 \pm 2.0$ & $8.64 \pm 1.8$ & $2.2(1.25,3.96) \mathrm{a}$ & $5.31(4.79,5.85) b$ \\
\hline
\end{tabular}


Converting concentrations per gram of tissue to an equivalent of Vapam, glucosinolate content in white mustard was calculated as Vapam at 25.7 liter/ha and in Indian mustard as Vapam at 22.1 liter/ha. The glucosinolate profile of broccoli was limited to a single indole glucosinolate, 3indolylmethyl, at the low mean concentration of $1.7 \pm 0.22 \mu \mathrm{mol} / \mathrm{g}\left(402 \mu \mathrm{mol} / \mathrm{m}^{2}\right)$ of dried tissue, which calculated to Vapam at 1.4 liter/ha.

Cover crop effects on weeds and weed seed. In the long-term experiment, densities of all but one weed species were unaffected by the mustard cover crops and all varied significantly among sampling times (Tables 5 and 6). Based on the maximum mean density of the three sampling dates, the most abundant weed species in the long-term experiment were hairy nightshade (Solanum physalifolium Rusby), nettleleaf goosefoot ( $C$. murale L.), chard (Beta vulgaris var. cicla (L.) K. Koch., a previous seed crop in the field), sowthistle (Sonchus sp.), and burning nettle (U. urens L.) (Table 6). Across all dates, densities of these weed species were typically similar among treatments, ranging from means of $0.63 \pm 0.12$ to $7.53 \pm 2.0$ weeds $/ \mathrm{m}^{2}$. Statistically, only nettleleaf goosefoot density varied among the treatment plots and only in July 2004 and May 2005 (Table 5). In July 2004, nettleleaf goosefoot density was higher in broccoli $\left(3.40 \pm 1.2\right.$ weeds $\left./ \mathrm{m}^{2}\right)$ than in any of the other cover-cropped plots (mean across other plots: $0.66 \pm 0.13$ weeds $/ \mathrm{m}^{2}$ ) and, in May 2005, significantly higher in broccoli $\left(3.25 \pm 0.66\right.$ weeds $\left./ \mathrm{m}^{2}\right)$ and rye $\left(3.50 \pm 1.8\right.$ weeds $\left./ \mathrm{m}^{2}\right)$ plots compared with mustard and fallow plots (mean: $1.55 \pm 0.35$ weeds $/ \mathrm{m}^{2}$ ). The other abundant weed species, and all species

Table 5. Analysis of variance results for effects of cover-cropping treatment and sampling date on weed densities in the long-term experiment in Salinas, CA

\begin{tabular}{|c|c|c|c|c|c|c|}
\hline \multirow[b]{2}{*}{ Weed species } & \multicolumn{2}{|c|}{ Treatment $^{\mathrm{x}}$} & \multicolumn{2}{|c|}{ Sampling date $\mathrm{y}$} & \multicolumn{2}{|c|}{$\begin{array}{c}\text { Treatment } \times \\
\text { sampling date }^{\mathrm{z}}\end{array}$} \\
\hline & $F$ & $P>F$ & $F$ & $P>F$ & $F$ & $P>F$ \\
\hline Nettleleaf goosefoot & 6.22 & 0.009 & 35.01 & $<0.0001$ & 2.63 & 0.038 \\
\hline Hairy nightshade & 0.76 & 0.577 & 165.73 & $<0.0001$ & 0.19 & 0.990 \\
\hline Chard & 0.13 & 0.969 & 3.85 & 0.0386 & 0.48 & 0.854 \\
\hline Sowthistle & 1.21 & 0.365 & 8.78 & 0.0018 & 0.42 & 0.898 \\
\hline Burning nettle & 2.26 & 0.135 & 16.32 & $<0.0001$ & 0.85 & 0.573 \\
\hline Shepherd's-purse & 1.54 & 0.264 & 8.98 & 0.0016 & 2.32 & 0.060 \\
\hline Total weeds & 1.07 & 0.420 & 362.18 & $<0.0001$ & 0.37 & 0.922 \\
\hline
\end{tabular}

${ }^{x}$ Source of variation: rye, broccoli, Indian mustard (Brassica juncea), white mustard (Sinapis alba), and fallow; numerator, denominator degrees of freedom $=4,10$.

y Source of variation: March 2003, July 2004, May 2005; numerator, denominator degrees of freedom $=2,20$.

${ }^{\mathrm{z}}$ Numerator, denominator degrees of freedom $=8,20$.

Table 6. Weed densities from each sampling time at the long-term experiment in Salinas, CA

\begin{tabular}{|c|c|c|c|}
\hline \multirow[b]{2}{*}{ Weed species } & \multicolumn{3}{|c|}{ Mean density $\left(\right.$ weeds $\left./ \mathrm{m}^{2}\right) \pm$ standard error of the mean ${ }^{z}$} \\
\hline & March 2004 & July 2004 & May 2005 \\
\hline Nettleleaf goosefoot & $1.23 \pm 0.27 \mathrm{a}$ & $0.29 \pm 0.27 b$ & $1.89 \pm 0.27 \mathrm{c}$ \\
\hline Hairy nightshade & $0.01 \pm 3.33 \mathrm{a}$ & $6.97 \pm 3.33 \mathrm{~b}$ & $15.61 \pm 3.33 b$ \\
\hline Chard & $0.52 \pm 0.33 \mathrm{a}$ & $0.59 \pm 0.33 \mathrm{ab}$ & $1.21 \pm 0.33 \mathrm{~b}$ \\
\hline Sow thistle & $0.13 \pm 0.29 \mathrm{a}$ & $1.73 \pm 0.29 b$ & $1.43 \pm 0.29 \mathrm{~b}$ \\
\hline Burning nettle & $0.17 \pm 0.17 \mathrm{a}$ & $0.84 \pm 0.17 \mathrm{~b}$ & $0.87 \pm 0.17 \mathrm{~b}$ \\
\hline Shepherd's-purse & $0.04 \pm 0.04 \mathrm{a}$ & $0.27 \pm 0.04 \mathrm{~b}$ & $0.07 \pm 0.04 \mathrm{a}$ \\
\hline Total weeds & $1.20 \pm 3.49 \mathrm{a}$ & $12.47 \pm 3.49 \mathrm{~b}$ & $20.42 \pm 3.49 b$ \\
\hline
\end{tabular}

${ }^{\mathrm{z}}$ For each weed species, means within a row followed by the same letter are not significantly $(P>$ 0.05 ) different according to pairwise $t$ tests. summed, varied statistically with sampling time (Table 5); generally, all were higher at sampling in July 2004 and May 2005 (Table 6). The exceptions to this trend were shepherd's-purse (Capsella bursa-pastoris (L.) Medikus), which was at the highest density in July 2004, and chard, which increased in density from March 2004 to May 2005 (Table 6).

Among the short-term experiments, mean total weed density across all plots was absolutely highest at Gonzales-A (12.2 \pm 2.7 weeds $\left./ \mathrm{m}^{2}\right)$ and at Spreckels $(8.8 \pm$ 1.9 weeds $/ \mathrm{m}^{2}$ ) and lowest at Somavia and Gonzales-D $(1.1 \pm 0.3$ and $1.1 \pm 0.5$ weeds/ $\mathrm{m}^{2}$, respectively). The Gonzales-A site was most diverse in weed species (common purslane, shepherd's purse, burning nettle, sowthistle, and nettleleaf goosefoot) compared with Somavia and Spreckels (shepherd's purse, burning nettle and sowthistle) and Gonzales-D (shepherd's-purse and sowthistle). Of all sites, only at Gonzales-A was weed density significantly affected by the mustard-covercrop treatment (Table 7). Common purslane was encountered at the highest mean density $\left(11.83 \pm 1.70\right.$ weeds $\left./ \mathrm{m}^{2}\right)$ of all weed species and was significantly lower $\left(F_{1,31}=8.53, P=0.007\right)$ in mustardcover-cropped plots $(9.65 \pm 2.07$ weeds $\left./ \mathrm{m}^{2}\right)$ than in fallow plots $(14.03 \pm$ 2.66 weeds $/ \mathrm{m}^{2}$ ). Total weed density also was significantly lower $\left(F_{1,31}=5.90, P=\right.$ $0.022)$ in mustard-cover-crop plots $(9.91 \pm$ 2.13 weeds $\left./ \mathrm{m}^{2}\right)$ than in fallow plots $(14.45$ \pm 3.28 weeds $/ \mathrm{m}^{2}$ ).

Of the weed species seed encountered in the long-term seed viability test, cover cropping affected viability only of hairy nightshade (Table 8). Here, the density of viable seed decreased significantly in plots cover cropped with white mustard from $46.0 \pm 11.5$ to $13.1 \pm 4.6$ viable seeds $/ \mathrm{m}^{2}$ from October 2003 to October 2004. The densities of viable seed of common purslane and of all species summed were significantly reduced from October 2003 to October 2004 but this effect was not unique to any treatment (Table 8). For common purslane, viable seed density decreased significantly from $91.9 \pm 14.1$ seeds $/ \mathrm{m}^{2}$ in October 2003 to $10.5 \pm 4.7$ seeds $/ \mathrm{m}^{2}$ in October 2004, and for all weed

Table 7. Mean ( \pm standard error of the mean) density for weed species found in short-term experiments with results of statistical tests for differences between plots with mustard cover crop and plots without mustard cover crops

\begin{tabular}{|c|c|c|c|c|c|c|c|c|c|c|c|c|}
\hline \multirow[b]{2}{*}{ Weed species } & \multicolumn{3}{|c|}{ Gonzales-A ${ }^{x}$} & \multicolumn{3}{|c|}{ Somavia } & \multicolumn{3}{|c|}{ Spreckels } & \multicolumn{3}{|c|}{ Gonzales-D ${ }^{x}$} \\
\hline & No. $/ \mathrm{m}^{2}$ & $F$ & $P>F$ & No. $/ \mathrm{m}^{2}$ & $F^{y}$ & $P>F$ & No. $/ \mathrm{m}^{2}$ & $F^{\mathbf{y}}$ & $P>F$ & No. $/ \mathrm{m}^{2}$ & $F$ & $P>F$ \\
\hline Common purslane & $* *$ & 8.53 & 0.007 & $-^{\mathrm{z}}$ & & & _- & & & _- & & \\
\hline Shepherd's-purse & $0.09 \pm 0.04$ & 2.48 & 0.126 & $0.15 \pm 0.03$ & 0.42 & 0.635 & & 0.01 & 0.932 & $0.04 \pm 0.02$ & 0.33 & 0.571 \\
\hline Burning nettle & $0.29 \pm 0.11$ & 3.89 & 0.058 & $0.25 \pm 0.07$ & 1.37 & 0.450 & $6.72 \pm 1.14$ & 1.66 & 0.327 & - & & \\
\hline Sowthistle & $0.37 \pm 0.19$ & 0.38 & 0.544 & $0.10 \pm 0.03$ & 0.08 & 0.825 & $0.23 \pm 0.06$ & 0.57 & 0.530 & $0.17 \pm 0.05$ & 0.38 & 0.544 \\
\hline Nettleleaf goosefoot & $0.03 \pm 0.01$ & 1.15 & 0.292 & $0.44 \pm 0.15$ & 3.24 & 0.323 & - & . & 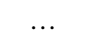 & - & & \\
\hline Total weeds & $* *$ & 5.90 & 0.216 & $1.08 \pm 0.24$ & 3.72 & 0.305 & $8.79 \pm 1.33$ & 1.80 & 0.312 & $0.38 \pm 0.08$ & 2.62 & 0.117 \\
\hline
\end{tabular}

${ }^{x}$ According to Friedman's nonparametric test; numerator, denominator degrees of freedom $=1,31$; $*$ indicates statistically significant treatment effect for which means are reported in the text.

${ }^{y}$ Numerator, denominator degrees of freedom $=1,2$.

${ }^{\mathrm{z}}$ Symbol: - indicates data were not collected for this species at this site. 
species summed, the viable seed density decreased significantly from $156.31 \pm 21.5$ seeds $/ \mathrm{m}^{2}$ in 2003 to $26.27 \pm 7.0$ seeds $/ \mathrm{m}^{2}$ in 2004 .

Analysis of the seed bag experiment revealed no differences in percent viability of burning nettle $\left(\chi^{2}=0.08, P=0.781\right)$, common purslane $\left(\chi^{2}=1.24, P=0.266\right)$, or common knotweed $\left(\chi^{2}=0.22, P=\right.$ $0.636)$ seed, but common chickweed seed viability was significantly $\left(\chi^{2}=4.53, P=\right.$ 0.045) higher in mustard-cover-cropped plots $(96.0 \pm 1.3 \%)$ compared with fallow plots $(90.0 \pm 2.5 \%)$.

\section{DISCUSSION}

The results of our experiments show varying effects of mustard cover cropping in our studies. Specifically, the incidence of lettuce drop was reduced by mustard cover cropping in the short-term experiments but not in the long-term experiment. Mustard cover crops suppressed different weed species in the long- and short-term experiments and affected seed viability of one species in the long-term experiment but not in the short-term experiment. The one consistent result between the long- and short-term experiments was that densities of soil sclerotia were not affected by mustard cover crops. Mustard cover cropping provided benefits to yield but consistent disease or weed suppression were not apparent in our studies.

Although sclerotia have been found to be susceptible to isothiocyanates in the laboratory (30), field studies have yet to translate this effect to sclerotial density (28). Despite estimated concentrations of isothiocyanates similar to the levels shown to affect sclerotia (30), we found sclerotial densities to be unaffected by the mustard cover crops. Our results from both the long- and short-term experiments are consistent with those of Pung et al. (28), who also found sclerotia densities to be unchanged as a result of mustard cover cropping. This lack of effect on sclerotia in our experiments may be related to inadequate glucosinolate conversion to isothiocyanates in the field. Conversion is an inefficient process and dependent on field and soil conditions, but especially on tissue pulverization and soil moisture $(21,22)$. Our studies were conducted across a range of soil types in both spring and fall and, although mustard cover crops were flail mowed and disked into moist soil at a stage when glucosinolate content in the plants is relatively high (29), none of the fields in these studies received any additional irrigation or precipitation after cover-crop incorporation. Therefore, field moisture may have been limiting to isothiocyanate release and leaching from the tissues so that Sclerotinia minor sclerotia were unaffected. The lack of effect on sclerotial density in the long-term experiment also may be related to overall low numbers of sclerotia in the fields $(<4$ scle- rotia per $100 \mathrm{~cm}^{3}$ of soil). In field studies with lettuce, Hao et al. (12) found that rotations with broccoli reduced soil sclerotia only in a field with high inoculum densities ( $>7$ sclerotia per $100 \mathrm{~cm}^{3}$ of soil) and not in a field with low densities $(<7$ sclerotia per $100 \mathrm{~cm}^{3}$ of soil). Detecting effects of the mustard cover crops may be particularly difficult when sclerotial densities are initially low.

Low soil densities of $S$. minor sclerotia corresponded to a low incidence of lettuce drop in most experiments. Inoculum density is usually correlated with lettuce drop incidence (8); therefore, overall lettuce drop averages of approximately 2.4 and $4.1 \%$ in the long-term and short-term experiments, respectively, are not surprising given the low densities of sclerotia that we observed in our study. In the long-term study, lettuce drop incidence was not reduced by mustard or broccoli cover cropping. This result, along with a lack of effect of the cover-crop treatments on sclerotia densities, suggests that the biofumigant potential of these Brassicaceae species may be particularly low in fields with low inoculum densities. Our results are consistent with those of Hao et al. (12) at the low-inoculum-density site in their study but differ from their results at the high-inoculum-density site, where rotations of broccoli in lettuce production reduced lettuce drop incidence. However, Hao et al (12) managed broccoli as a vegetable crop, whereas we grew broccoli as a cover crop, which resulted in an atypically low biomass. This difference between the studies may help explain these contrasting results. Sclerotial density in the long-term experiment was higher over the second season after two lettuce crops, compared with densities from the first season. Despite the low incidence of lettuce drop in the long-term experiment, sequential infections may have served to increase sclerotial density in the soil (31). These results are also consistent with the findings of Hao et al. (12), who found annual in- creases of soil sclerotia at the lowsclerotia-density field.

Across the short-term experiments, lettuce drop incidence was significantly reduced in mustard-cover-cropped plots even though we found no effect of the mustard on soil sclerotia densities across experiments. Lettuce drop incidence was typically low and, therefore, the absolute reduction in lettuce drop was also quite low; however, the percent reduction was significant. Pung et al. (28) also found that mustard cover cropping reduced disease incidence without affecting sclerotia density. The results together indicate that the mode of action of mustard cover crops against $S$. minor is disease suppression. In our experiments, however, we cannot be certain that the effect on lettuce drop in these plots may have been accentuated by factors not examined by or controlled in our study. Cropping history of individual fields, moisture distribution as affected by irrigation practices (34), and the distribution of individual sclerotia all play a role in disease incidence.

Mustard cover cropping in our study resulted in little to no weed suppression in the field. Differences in weed densities were observed only for two species and were not related to the mustard cultivars. In the long-term experiment, higher densities of nettleleaf goosefoot are most likely explained by the poor growth and low cover of the broccoli plantings. In a study examining the effects of cover crops on weed management, Brennan and Smith (3) found that the low plant density of a legume-oat cover crop mixture resulted in high weed biomass compared with plots cover cropped more densely with oat or mustard. The average increase in nettleleaf goosefoot in the rye plots on the last sampling date is the result of two samples in one replicate with unusually high densities of this weed and is not representative of the remaining samples from the rye plots. In the short-term experiments, out of five different weed species occurring at these

Table 8. Results of statistical tests of changes in viable weed seed densities due to cover-crop treatments in long-term experimental plot in Monterey County, CA

\begin{tabular}{|c|c|c|c|c|c|c|}
\hline \multirow[b]{2}{*}{ Weed species $^{\mathrm{z}}$} & \multicolumn{2}{|c|}{ Treatment $^{\mathrm{w}}$} & \multicolumn{2}{|c|}{ Sampling time ${ }^{\mathrm{x}}$} & \multicolumn{2}{|c|}{$\begin{array}{c}\text { Treatment } \times \\
\text { sampling time }^{\mathrm{y}}\end{array}$} \\
\hline & $F$ & $P>F$ & $\boldsymbol{F}$ & $P>F$ & $F$ & $P>F$ \\
\hline Hairy nightshade & 2.67 & 0.055 & 4.76 & 0.014 & 2.40 & 0.041 \\
\hline Nettleleaf goosefoot & 1.25 & 0.174 & 0.66 & 0.783 & 0.86 & 0.789 \\
\hline Common purslane & 0.10 & 0.986 & 25.62 & $<0.0001$ & 0.38 & 0.931 \\
\hline Shepherd's-purse & 0.55 & 0.851 & 0.56 & 0.907 & 1.11 & 0.331 \\
\hline Sow thistle & 0.73 & 0.635 & 0.09 & 0.998 & 1.08 & 0.353 \\
\hline Swiss chard & 0.94 & 0.479 & 1.18 & 0.364 & 0.43 & 0.926 \\
\hline Total weed species & 0.26 & 0.919 & 22.71 & $<0.0001$ & 0.27 & 0.973 \\
\hline
\end{tabular}

${ }^{\mathrm{w}}$ Source of variation: rye, broccoli, Indian mustard (Brassica. juncea), white mustard (Sinapis alba), and fallow with numerator, denominator degrees of freedom $=4,28$.

${ }^{\mathrm{x}}$ Source of variation: pre-cover-crop incorporation (September 2003), first post-cover-crop incorporation (October 2003), second post-cover-crop incorporation (October 2004) with numerator, denominator degrees of freedom $=2,28$.

${ }^{y}$ Numerator, denominator degrees of freedom for long-term experiment $=8,28$.

${ }^{\mathrm{z}}$ Weed species listed are those for which means could be calculated and tested. Seed of other weed species may have been present in soil samples but were viable in insufficient replication for analysis. 
sites, only common purslane was affected by the mustard cover crop. The reduction in common purslane density is consistent with results from Wang et al. (37), where common purslane densities were lower in plots cover cropped with a cultivar of white mustard compared with plots cover cropped with cultivars of Indian mustard, sorghum, and oilseed radish. Generally, in other studies where mustard cover cropping has inhibited weed germination, glucosinolate concentrations per unit area were considerably higher than concentrations calculated from our long-term experiment. For instance, Norsworthy and Meehan (25) reported glucosinolate concentrations ranging from 8,600 to 26,700 $\mu \mathrm{mol} / \mathrm{m}^{2}$ compared with our measurements of mustard ranging from 6,523 to 7,589 $\mu \mathrm{mol} / \mathrm{m}^{2}$.

Generally, mustard cover crops did not affect the weed seed bank. In the long-term experiment, however, hairy nightshade seed viability was reduced in the white mustard plots of the long-term experiment. The mechanism for this effect is unclear but, possibly, hairy nightshade seed may be more sensitive to glucosinolate products of the mustard than other weed seed. In the laboratory, Petersen et al. (27) found that, with methyl isothiocyanate at $5 \mathrm{mg} / \mathrm{liter}$, germination percentage decreased with decreasing seed size of five weed species. Other small-seeded weeds represented in the weed seed bank of our experiment (e.g., common purslane) were not affected; therefore, additional studies are needed to confirm this effect and mechanism.

In the long-term experiment, mustard cover cropping increased yield when compared with leaving fields fallow and, although not statistically, mustard cover cropping absolutely improved yield over rye and broccoli cover crops as well. Cover crop biomass incorporated into plots in each of the two seasons differed among the cover crops, yet these differences did not correspond to the differences in lettuce yield among the treatment plots. Even though rye produced more biomass than the mustard cover crops, the total nitrogen added to plots by these cover crops was similar (approximate mean of $180 \mathrm{~kg} / \mathrm{ha}$; R. F. Smith, unpublished), yet only the mustard-cover-cropped plots yielded significantly more lettuce than the fallow plots. Lettuce drop incidence was absolutely higher in the mustard plots compared with rye plots; therefore, it appears that the mustard cultivars may confer other benefits to the lettuce crop that were not measured in our study. The broccoli-covercropped plots received the least amount of biomass and nitrogen, and experienced higher weed pressure and a similar level of lettuce drop, yet mean lettuce yield from these plots was not significantly different from yields of the mustard plots. Clearly, many factors competed to influence yield in our studies, and none of the factors that we measured predominated in the yield outcome.

Mustard cover crop effects in our longand short-term experiments were inconsistent, particularly on disease incidence. Although the levels of glucosinolates in the mustard tested here were similar to those in other studies showing disease or weed suppression, we did not see definitive trends in pest suppression. When compared with label rates for Vapam, the levels of glucosinolates in our mustard cover crops were clearly inadequate for suppression of disease and weeds in lettuce, even with the generous conversion rate that we assumed. In processing tomato production, Hartz et al. (14) found mustard cover crops to be ineffective against soilborne disease and suggested that total glucosinolate concentrations are less important for biofumigant potential than are field conditions that regulate isothiocyanate release and retention in the soil. In lettuce cropping systems, it will be necessary to better understand how these chemicals behave across a variety of conditions in order to approach full biofumigant potential in the field.

\section{ACKNOWLEDGMENTS}

We thank J. Davis, D. Miltz, and P. Headley for laboratory and field assistance with this project; J. Hoeksema for statistical consultation and assistance; and M. Manzoni, Manzoni Farms, B. Waltrip, Secondo Farms, R. Yokota, Tanimura and Antle, and D. Caprarra, RC Farms, for hosting the field trials. This manuscript was greatly improved by comments from C. Grau, B. Shew, and three anonymous reviewers. Funding for these trials was provided by the California Lettuce Research Board.

\section{LITERATURE CITED}

1. Angus, J. F., Gardner, P. A., Kirkegaard, J. A., and Desmarchelier, J. M. 1994. Biofumigation: Isothiocyanates released from Brassica roots inhibit growth of the take-all fungus. Plant Soil 162:107-112.

2. Boydston, R. A., and Hang, A. 1995. Rapeseed (Brassica napus) green manure crop suppresses weeds in potato (Solanum tuberosum). Weed Technol. 9:669-675.

3. Brennan, E. B., and Smith, R. F. 2005. Winter cover crop growth and weed suppression on the central coast of California. Weed Technol. 19:1017-1024.

4. Brown, P. D., and Morra, M. J. 1996. Hydrolysis products of glucosinolates in Brassica napus tissues as inhibitors of seed germination. Plant Soil 181:307-316.

5. Cassell, D. L. 2002. A randomization test wrapper for SAS PROCs (paper 251-27). In: SAS User Group International (SUGI) 27, Cary, NC.

6. Daun, J. K., DeClerq, D. R., and McGregor, D. I. 1989. Analysis of Glucosinolates in Canola and Rapeseed. Agriculture Canada, Canadian Grain Commission, Winnipeg, MB, Canada.

7. Daun, J. K., and McGregor, D. I. 1991. Glucosinolate in seeds and residues. Pages 185226 in: Analysis of Oilseeds, Fats and Fatty Foods. J. B. Rossell and J. L. R. Pritchard, eds. Elsevier Publishing Co., New York.

8. Dillard, H. R., and Grogan, R. G. 1985. Relationship between sclerotial spatial patterns and density of Sclerotinia minor and the incidence of lettuce drop. Phytopathology 75:90-94.

9. Fenwick, G. R., Heaney, R. K., and Mawson, R. 1989. Glucosinolates. Pages 1-41 in: Toxi- cants of Plant Origin, Vol. II. Glycosides. P. R. Cheeke, ed. CRC Press, Inc., Boca Raton, FL.

10. Flemion, F., and Poole, H. 1948. Seed viability tests with 2,3,5-triphenyltetrazolium chloride. Contrib. Boyce Thompson Inst. 15:243-258.

11. Grabe, D. F., ed. 1970. Tetrazolium testing handbook for agricultural seeds. Contribution No. 29 to the Handbook on Seed Testing. Assoc. Offic. Seed Anal. (no location).

12. Hao, J., Subbarao, K. V., and Koike, S. T. 2003. Effects of broccoli rotation on lettuce drop caused by Sclerotinia minor and on the population density of sclerotia in soil. Plant Dis. 87:159-166.

13. Haramoto, E. R., and Gallandt, E. R. 2005. Brassica cover cropping: I. Effects on weed and crop establishment. Weed Sci. 53:695-701

14. Hartz, T. K., Johnstone, P. R., Miyao, E. M. and Davis, R. M. 2005. Mustard cover crops are ineffective in suppressing soilborne disease or improving processing tomato yield HortScience 40:2016-2019.

15. Jackson, L., Mayberry, K., Laemmlen, F., Koike, S., Schulbach, K., and Chaney, W. 1996. Iceberg lettuce production in California. Publication 7215, Division of Agriculture and Natural Resources, University of California, Davis.

16. Kirkegaard, J. A., and Sarwar, M. 1998. Biofumigation potential of brassicas. I. Variation in glucosinolate profiles of diverse field-grown brassicas. Plant Soil 201:71-89.

17. Lanini, W. T., and LeStrange, M. 1991. Lowinput management of weeds in vegetable fields. Calif. Agric. 45:11-13.

18. Larkin, R. P., and Griffin, T. S. 2007. Control of soilborne potato diseases using Brassica green manures. Crop Prot. 26:1067-1077.

19. Malone, C. R. 1967. A rapid method for enumeration of viable seeds in the soil. Weeds 15:381-382.

20. Manici, L. M., Lazzeri, L., and Palmieri, S 1997. In vitro fungitoxic activity of some glucosinolates and their enzyme-derived products toward plant pathogenic fungi. J. Agric. Food Chem. 45:2768-2773.

21. Matthiessen, J. N., and Kirkegaard, J. A. 2006 Biofumigation and enhanced biodegradation: Opportunity and challenge in soilborne pest and disease management. Crit. Rev. Plant Sci. 25:235-265.

22. Morra, M. J., and Kirkegaard, J. A. 2002. Isothiocyanate release from soil-incorporated Brassica tissues. Soil Biol. Biochem. 34:16831690.

23. Muehlchen, A., Rand, R., and Parke, J. 1990. Evaluation of crucifer green manures for controlling Aphanomyces root rot of peas. Plant Dis. 74:651-654.

24. Norsworthy, J. K., Brandenberger, L., Burgos, N. R., and Riley, M. 2005. Weed suppression in Vigna unguiculata with a spring-seeded Brassicaceae green manure. Crop Prot. 24:441447.

25. Norsworthy, J. K., and Meehan, J. T. 2005. Use of isothiocyanates for suppression of Palmer amaranth (Amaranthus palmeri), pitted morningglory (Ipomoea lacunosa), and yellow nutsedge (Cyperus esculentus). Weed Sci. 53:884-890.

26. Olivier, C., Vaughn, S. F., Mizubuti, E. S. G. and Loria, R. 1999. Variation in allyl isothiocyanate production within Brassica species and correlation with fungicidal activity. J. Chem. Ecol. 25:2687-2701.

27. Petersen, J., Belz, R., Walker, F., and Hurle, K. 2001. Weed suppression by release of isothiocyanates from turnip-rape mulch. Agron. J. 93:37-43.

28. Pung, H., Aird, P. L., and Cross, S. 2004. The use of Brassica green manure crops for soil improvement and soilborne disease management. In: Proc. Third Australas. Soilborne Dis. Symp. Barossa, SA, Australia. 
29. Sarwar, M., and Kirkegaard, J. A. 1998. Biofumigation potential of brassicas. II. Effect of environment and ontogeny on glucosinolate production and implications for screening. Plant Soil 201:91-101.

30. Smolinska, U., and Horbowicz, M. 1999. Fungicidal activity of volatiles from selected cruciferous plants against resting propagules of soil-borne fungal pathogens. J. Phytopathol. 147:119-124.

31. Subbarao, K. V. 1998. Progress toward integrated management of lettuce drop. Plant Dis. 82:1068-1078

32. Subbarao, K. V., Hubbard, J. C., Dacuyan, S., Koike, S. T., and Jackson, L. E. 1994. Evaluation of three quantitative assays for Sclerotinia minor.
Phytopathology 84:1471-1475.

33. Subbarao, K. V., Hubbard, J. C., and Koike, S. T. 1999. Evaluation of broccoli residue incorporation into field soil for Verticillium wilt control in cauliflower. Plant Dis. 83:124129.

34. Subbarao, K. V., Hubbard, J. C., and Schulbach, K. F. 1997. Comparison of lettuce diseases and yield under subsurface drip and furrow irrigation. Phytopathology 87:877-883.

35. Vallad, G. E., Bhat, R. G., Koike, S. T., Ryder, E. J., and Subbarao, K. V. 2005. Weedborne reservoirs and seed transmission of Verticillium dahliae in lettuce. Plant Dis. 89:317-324.

36. Vaughn, S. F., and Boydston, R. A. 1997. Volatile allelochemicals released by crucifer green manures. J. Chem. Ecol. 23:2107-2116.

37. Wang, G., Ngouajio, M., and Warncke, D 2008. Nutrient cycling, weed suppression, and onion yield following Brassica and sorghum sudangrass cover crops. HortTechnology 18:68-74.

38. Xiao, C. L., Subbarao, K. V., Schulbach, K. F., and Koike, S. T. 1998. Effects of crop rotation and irrigation on Verticillium dahliae microsclerotia in soil and wilt in cauliflower. Phytopathology 88:1046-1055.

39. Zerbini, F. M., Koike, S. T, and Gilbertson, R. L. 1995. Biological and molecular characterization of lettuce mosaic potyvirus isolates from the Salinas Valley of California Phytopathology 85:746-752. 